\title{
Studies on Reducing Thrips Populations in Onion by Optimizing Nitrogen and Potash Levels
}

\author{
M. K. Pathak ${ }^{1 *}$, M. K. Pandey ${ }^{1}$, R. C. Gupta ${ }^{1}$, A. K. Tailor ${ }^{1}$ and P. K. Gupta ${ }^{2}$ \\ ${ }^{1}$ National Horticultural Research and Development Foundation, (NHRDF) Regional Research \\ Station, Chitegaon Phata, Nashik (Maharashtra), India \\ ${ }^{2}$ Head office, NHRDF, Janakpuri, New Delhi, India \\ *Corresponding author
}

A B S T R A C T

\begin{tabular}{|l|}
\hline Ke y w or d s \\
Onion, Thrips, Fertilizers, \\
Nitrogen, Potash
\end{tabular}

\section{Introduction}

Onion (Allium cepa L.) is grown all over world and is a favourite vegetable in India. It is relished mostly as salad and Indian cuisine is incomplete without onion. India is the second largest onion producing country in the world (FAO, 2014). Thrips (Thrips tabaci Lindeman) is a regular and potential pest of onion and cause considerable losses as high as 90\% in quality and yield (Gupta et al., 1984, Dharmasena, 1998., Sudharma and Nair, 1999). Thrips attack onion at all the stages of crop growth but their count increases from bulb initiation and remain high up to bulb development and maturity. Both nymphs and adult cause damage directly through feeding and indirectly through the transmission of lethal plant viruses. It is difficult to control this pest with insecticides because of its small size and cryptic habits (Lewis, 1997). Failure to control this pest by timely and effective means causes considerable damage and result in immense economic loss by remarkably reduced yield (Anonymous. 2000, Jaun, 2002). Fertilizers i.e. nitrogen (N), phosphorous $\left(\mathrm{P}_{2} \mathrm{O}_{5}\right)$ and potassium $(\mathrm{k})$ play an important role that promote growth and productivity of onion crop. Phosphorous is required for root growth and development of plant (Uchida, 2000). They are not only improving crop yield, but also influence crop suitability for insect development, depending on the type of fertilizer and pest species (Van 
Emden, 1966: Kogan, 1994). Magdoff and Van. (2000) suggested farming practices that cause nutrition imbalance can also lower pest resistance.

The recommendation is to apply $100-120 \mathrm{Kg}$ of nitrogen per hectare, but there is a wide range in the amount of nitrogen added to the crop. Some growers apply nitrogen at planting and supplement with foliar applications during the season. However, recent work has shown that foliar-applied nitrogen will not improve bulb size or yield (Warncke 2008). Westerveld et al., (2002) reported that onion yield did not differ between a conventional nitrogen treatment and one that received twice the amount of nitrogen. The Vegetative growth of onion plants and minerals uptake increased with increasing nutrients like $\mathrm{P}_{2} \mathrm{O} 5$ and $\mathrm{N}$ that affect the infestation of Thrips tabacai (Malik et. al.; 2009; Bandi and Sivasubramanian, 2012).Therefore, the present study were aimed to study different doses of nitrogen and potash on the infection of Thrips tabaci.

\section{Materials and Methods}

The field experiment was conducted at NHRDF, Regional Research Station, Chitegaon, Nashik, Maharashtra during Rabi 2014-15, 2015-16 and 2016-17 seasons. The seedlings of onion variety Agrifound Light Red were transplanted in a bed size of $3.0 \mathrm{x}$ $1.20 \mathrm{~m}$ at $15 \mathrm{~cm} \times 10 \mathrm{~cm}$ spacing. Randomized Block Design with 4 replications was followed. The treatments evaluated were T1 (0 \% Nitrogen), T2 (50\% nitrogen of the recommended rate as basal application through calcium nitrate), T3 (75\% Nitrogen of the recommended rate as basal application through calcium nitrate). T4 (100\% nitrogen of the recommended rate as basal application through calcium nitrate).T5 (50\% nitrogen of the recommended rate as basal application through Urea \& potash through sulphate of potash as basal application),T6(75\% nitrogen of the recommended rate as basal application through Urea \& Potash through sulphate of potash as basal application), T7(100\%nitrogen of the recommended rate as basal application through Urea \& Potash through sulphate of potash as basal application) and control (Recommended dose). The crop was harvested after attaining the maturity. The data on thrips (Nymphs/plant) population were counted at the inner most leaves in 10 plant marked randomly in each treatment.

All other agronomical practices were performed uniformly as per need in all the treatments.

\section{Results and Discussion}

The data presented in (Table 1) revealed that thrips population at different stages of growth of crop and gross yield were influenced significantly due to different treatments. A mixed trend of increasing and decreasing the thrips population was observed. The lowest mean thrips population (22.56 nymphs/plat) were recorded in T1 (0 \% Nitrogen).The highest gross yield (306.89 q/ha) and marketable yield $(279.73 \mathrm{q} / \mathrm{ha})$ were recorded in T4 $(100 \%$ nitrogen of the recommended rate as basal application through calcium nitrate) and were found at par with T3 $(75 \%$ Nitrogen of the recommended rate as basal application through calcium nitrate).The lowest gross yield $(249.05 \mathrm{q} / \mathrm{ha})$ was recorded in T1. The highest C: B ratio 1:1.45 was recorded inT3.

A positive correlation between onion thrips and nitrogen fertilizer has been observed. Cultural practices, e.g., crop fertilization can affect susceptibility of plants to insect pest by altering plant tissue nutrient levels (Altieri and Nicholls, 2003). However; they reported that excessive use of chemical fertilizers can cause nutrient imbalances and lower pest resistance. Recommended rate of $\mathrm{N}, \mathrm{P}$, and $\mathrm{K}$, three times 
of the recommended rate of organic fertilizer, and control without fertilizer application were similar in relation to density of thrips (Goncalves and Sousa, 2004). Furthermore, six rates of $\mathrm{N}$, low $(50 \mathrm{~kg} \mathrm{~N} / \mathrm{ha})$ and optimum $(150 \mathrm{~kg} \mathrm{~N} / \mathrm{ha})$ were applied to soil, but they did not affect on the abundance of T.tabaci on onions, although the density of thrips (7.6 thrips/plant) was decreased in $150 \mathrm{~kg} \mathrm{~N} / \mathrm{ha}$ (Malik et al., 2009). They also reported that a total of 13 thrips/plant were observed with application of higher rate of $\mathrm{N}$ (200 and 250 $\mathrm{kg} / \mathrm{ha}$ ), which increased the population of thrips up to $73.90 \%$.However, it is confirmed by Martin and Workman (2006) that agronomic and $\mathrm{N}$-fertilizer factor affected the susceptibility of onion bulbs to onion thrips. Combination of NPK + FYM + bio-fertilizers + neem cake recorded the lowest incidence of T.tabaci on compared to the treatments receiving inorganic NPK alone (Bandi and Sivasubramanian, 2012).Patel and Patel (2012) found that $100 \mathrm{~kg} \mathrm{~N} / \mathrm{ha}$ recorded significantly lowest thrips (9.23 thrips/plant) density compared to $50 \mathrm{~kg} \mathrm{~N} / \mathrm{ha}$ (10.13 thrips /plant), but the infestation was minimum when the crop served with $50 \mathrm{~kg} \mathrm{~N} / \mathrm{ha}$ on compared to $150 \mathrm{~kg} \mathrm{~N} / \mathrm{ha}$. Onion yield was also increased as a result of $\mathrm{P}_{2} \mathrm{O}_{5}$ compared to $\mathrm{N}$ and $\mathrm{K}$ fertilizer (Goncalves et al., 2009).

Similarly, Malik et al., (2009) reported that yield of onion was increased with $200 \mathrm{~kg} \mathrm{~N} / \mathrm{ha}$. Whereas, the highest bulb yield (19.50 t/ha) was recorded with a recommended doses of inorganic nutrients along with farm yard manure, bio-fertilizers, and neem cake (Bandi and Sivasubramanian, 2012). Patel and Patel (2012) suggested that the yield of onion bulb was significantly highest $(60.74 \mathrm{t} / \mathrm{ha})$ with $150 \mathrm{Kg} \mathrm{N} / \mathrm{ha}$, and it was at par with treatment of $100 \mathrm{~kg} \mathrm{~N} / \mathrm{ha}$ which yielded $57.80 \mathrm{t} / \mathrm{ha}$ onion bulb as compared to $50 \mathrm{~kg} \mathrm{~N} / \mathrm{ha}$, However, Malik et al., (2009) suggested that a rapid decrease in the yield was obtained with $200-250 \mathrm{~kg} / \mathrm{ha}$,

Table.1 Studies on reducing thrips populations in onion by optimizing nitrogen and potash levels (Pooled data 2014-15, 2015-16, 2016-17)

\begin{tabular}{|c|c|c|c|c|c|c|c|c|c|c|c|}
\hline \multirow[t]{2}{*}{ Treatments } & \multicolumn{7}{|c|}{ Thrips Population (Nymphs/plant) } & \multirow{2}{*}{$\begin{array}{l}\text { Over } \\
\text { all } \\
\text { Mean } \\
\text { (Thrips } \\
\text { Pop.) }\end{array}$} & \multirow{2}{*}{$\begin{array}{c}\text { Gross } \\
\text { yield } \\
\text { (q/ha) }\end{array}$} & \multirow{2}{*}{$\begin{array}{c}\text { Market- } \\
\text { able } \\
\text { yield } \\
\text { (q/ha) }\end{array}$} & \multirow{2}{*}{$\begin{array}{c}\text { C:B } \\
\text { Ratio }\end{array}$} \\
\hline & $\begin{array}{c}20 \\
\text { DAT }\end{array}$ & $\begin{array}{c}30 \\
\text { DAT }\end{array}$ & $\begin{array}{c}40 \\
\text { DAT }\end{array}$ & $\begin{array}{c}50 \\
\text { DAT }\end{array}$ & $\begin{array}{c}60 \\
\text { DAT }\end{array}$ & $\begin{array}{c}70 \\
\text { DAT }\end{array}$ & $\begin{array}{c}80 \\
\text { DAT }\end{array}$ & & & & \\
\hline \multicolumn{12}{|l|}{ Treatments } \\
\hline $\mathrm{T} 1$ & 11.27 & 19.61 & 23.95 & 19.81 & 25.68 & 30.33 & 27.07 & 22.56 & 249.05 & 226.21 & 1:0.09 \\
\hline T2 & 12.46 & 20.92 & 28.78 & 26.17 & 35.57 & 37.54 & 35.04 & 28.56 & 262.98 & 237.58 & 1:0.03 \\
\hline T3 & 13.28 & 22.30 & 29.81 & 30.92 & 38.23 & 40.78 & 37.68 & 31.11 & 300.33 & 275.50 & $1: 1.45$ \\
\hline T4 & 18.30 & 24.19 & 33.21 & 36.19 & 45.59 & 46.93 & 41.52 & 35.41 & 306.89 & 279.73 & $1: 0.23$ \\
\hline T5 & 16.86 & 23.00 & 28.03 & 26.58 & 33.05 & 35.50 & 37.93 & 29.11 & 294.03 & 268.48 & $1: 1.08$ \\
\hline T6 & 15.23 & 22.93 & 29.03 & 29.80 & 32.88 & 41.37 & 41.03 & 30.79 & 297.12 & 269.54 & 1:0.87 \\
\hline T7 & 17.37 & 25.14 & 31.84 & 39.19 & 46.80 & 51.45 & 36.70 & 35.98 & 287.62 & 263.79 & $1: 0.08$ \\
\hline T8 & 17.48 & 25.95 & 28.08 & 33.17 & 36.85 & 39.01 & 37.40 & 31.59 & 285.60 & 263.27 & - \\
\hline S.Em \pm & 0.77 & 1.15 & 1.22 & 1.13 & 1.10 & 1.36 & 1.11 & 0.45 & 4.44 & 4.38 & - \\
\hline CD at $5 \%$ & 1.54 & 2.30 & 2.44 & 2.26 & 2.20 & 2.72 & 2.22 & 0.90 & 8.88 & 8.76 & - \\
\hline
\end{tabular}


Fig.1 Overall Mean Thrips Population in different treatments

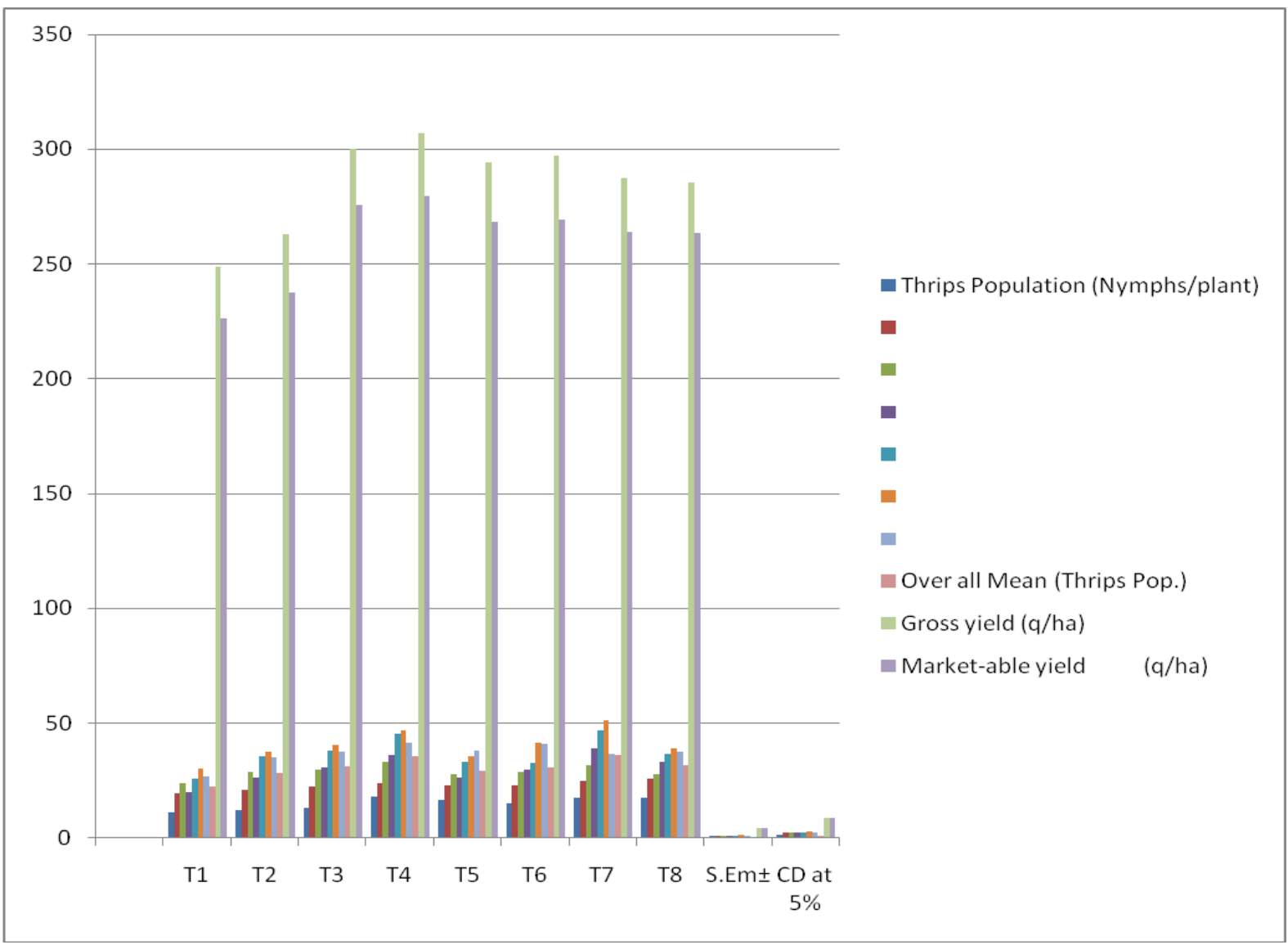

The study concludes that an excessive dose of nitrogen fertilizer may produce lush green plants, which will attract pest infestation, moreover higher dose of fertilizer also affect the crop maturity and heavy attack of sucking pests.

Based on the studies made during rabi 2014$15,2015-16$ \& 2016-17 it could be concluded that the lowest thrips population were recorded in without $\mathrm{N}$ application (0\% nitrogen).

\section{References}

Agumas B, Abewa A, Abebe D (2014).Response of irrigated onion (Allium cepa L.) to nitrogen and phosphorus firtilizers at Ribb and Koga irrigation schemes in Amhara Region,
North Western Ethiopia. Int.Res.J.Agric.Sci.Soil Sci. 4: 95-100.

Altieri, MA, Nicholls CI (2003). Soil fertility management and insect pests: harmonizing soil and plant health in agro ecosystems. Soil Tillage Res. 72: 203-211.

Anonymous (2000). Annual Report: National Research Centre for onion and Garlic. pp.63-64

Bandi SM, Sivasubramanian P (2012). Role of induced host plant resistance in the management of Thrips tabaci Lindeman (Thripide: Thysanoptera) in onion. Agric. Sci. Dig. 32: 219-223.

Boateng CO (2012). Physiological responses of onion germplasms to iris yellow spot virus and onion thrips (Thrips tabaci). (Dissertation).Dep. Bioagric. Sci. Pest 
Manag., Colo. State Univ., Fort Collins, USA.

Dharmasena, C.M.D. (1998).Present status of managing leaf curl complex in north central province of Sri-Lanka. Trop.Agric.Res.Extn., 1(2):154-158.

Diaz-Montano J, Fuchs M, Nault BA, Fail J, Shelton AM (2010. Evaluation of onion cultivars for resistance to onion thrips (Thysanoptera: Thripidae) and Iris yellow spot virus. J. Econ. Entomol. 103, 925-937.

FAO, Food and Agriculture Organization (2014). http://faostat3.fao.org/faostatgateway. Accessed on 20 -11- 2014.

Goncalves PADS, Sousa e Silva CR (2003). Impact of the organic fertilization on onion thrips incidence. Hortic. Bras. 21: 3, 459-463.

Goncalves PADS, Sousa e Silva CR (2004). Mineral and organic fertilization and onion thrips, Thrips tabaci Lind. (Thysanoptera: Thripidae) population density. Cienc. Rural, 34: 4, 1255-1257.

Goncalves PADS, Wordell Filho JA, Kurtz C (2009). Effects of fertilization on thrips and downy mildew incidence and on the yield of onion. Agropecu. Catarin. 22: $1,57-60$.

Gupta, R.P., Srivastva, V.K., Bhardwaj, B.S. and Pandey U.B. (1984). Chemical control of thrips tabaci L.infesting onion crop. J.Ent.Res., 8(2)196-198.

Juan, Anciso (2002). Onion world, 18(3):10.

Kogan M (1994). Plant resistance in pest management, in: Metcalf, R.L., Luckmann W.H. (Eds.). Introduction to Pest Management, third ed. John Wiley and Sons, Inc., New York, pp. 73-128.

Lewis (1997).Pest thrips in perspective-In: Lewis, T. (ed): Thrips as crop pest CAB international, Wallingford, UK: 1-14.

Magdoff F, Van Es H (2000). Building Soils for Better Crops, second ed. Beltsville, Sustainable Agriculture Network, $p p$. 230.
Malik MF, Nawaz M, Ellington J, Sanderson R, El-Heneidy AH (2009). Effect of different nitrogen regimes on onion thrips, Thrips tabaci Lindeman, on onions, Allium cepa L. Southwest. Entomol. 34: 3, 219-225.

Marschner H (1995). Mineral Nutrition of Higher Plant, second ed. Plants Gulf Professional Publ. pp. 889.

Martin NA, Workman PJ (2006). A new bioassay for determining the susceptibility of onion (Allium cepa) bulbs to onion thrips, Thrips tabaci (Thysanoptera: Thripidae). N. Z. J. Crop Hortic. Sci. 34:85-92.

Pandey S, Mishra RK, Singh AK, Singh SK (2012. Studies on entomopathogenic fungus for management of onion thrips to produce quality onion. Biopestic. Int. $8: 2,165-167$.

Patel HC, Patel JJ (2012). Impact of Different Nitrogen Levels and Irrigation Intervals on Incidence of Thrips (Thrips tabaci Lindaman) Infesting Onion (Allium cepaL.). Int. e-J. 1:4, 509-513.

Resende GM, Costa ND, Yuri JE (2016). Efeito de doses de fosforo na produtividade e armazenamento poscolheita de dois cultivares de cebola.Rev. Ceres 63:249-255.

Shaheen AH, Mona M, Abdel M, Aisha AM, Fatma AR (2007). Natural and chemical phosphorus fertilizers as affected onion plant growth, bulb yield and its some physical and chemical properties. Aust. J. Basic Appl. Sci. 1, 519-524.

Simon T, Tora M, Shumbulo A, Urkato S (2014).The effect of variety, Nitrogen and Phosphorous Fertilization on Growth and bulb yield of onion (Allium cepa L.) at Wolaita, Southern, Ethopia. J.Biol.Agric. Health 4: 89-97.

Srivastava KJ, Gupta RP, Sharma HK, Pandey NK (2005). Effect of nitrogen doses and irrigation intervals on the stemphylium blight disease and thrips in 
onion bulb crop. News Lett. Natl. Hortic. Res. Dev. Found. 25: 1, 6-9.

Sudharma, K. and Nair, G.M. (1999). Assessment of loss caused by polyphagotarsonemus latus on chill. Entomol, 24(1)197-98

Trani PE, Breda junior M, Factor TL (2014).Calagem e adubacao dacebola (Allium cepa L.).Campinas: Instituto Agronomico35p.

Uchida R (2000).Essential nutrients for plant growth: nutrient functions and deficiency symptoms, in: Silva, JA., Uchida, R. (Eds). Plant nutrient management in Hawaii, s Soils, Approaches for tropical and subtropical
Agriculture. Coll.Trop.Agric.Resour., Univ. Hawaii at Manoa, pp.31-55.

Van Emden HF (1966). Plant insect relationships and pest control World Rev.Pest control, 5, 115-123.

Warncke, D.D. 2008. Foliar fertilization of onions, pp. 49-51. In: Proceedings of the 2008 Empire State Fruit and vegetable Expo. February 12-14, 2008. Syracuse, NY. Cornell Cooperative Extension and New York State Vegetable growers Association.

Westerveld SM, McDonald MR, ScottDupree CD, McKeown AW (2002). The effect of nitrogen on insect and diseases pests of onions, carrots, and cabbage. J.Veg.Crop Prod. 8: 2, 87-99.

\section{How to cite this article:}

Pathak M. K., M. K. Pandey, R. C. Gupta, A. K. Tailor and Gupta P. K. 2018. Studies on Reducing Thrips Populations in Onion by Optimizing Nitrogen and Potash Levels. Int.J.Curr.Microbiol.App.Sci. 7(07): 4161-4166. doi: https://doi.org/10.20546/ijcmas.2018.707.485 